\title{
Reviewing Malaysia's Renewable Energy Policies: A Management Framework Perspective
}

\author{
Pei Y. Ong, Christina M. M. Chin, and Eng H. Yap
}

\begin{abstract}
This paper reviews current renewable energy policies in Malaysia to develop an understanding of the country's progress in achieving energy sustainability given that fossil fuel resources are facing its eventual and gradual depletion; hence the need to develop a project management framework with reference to Malaysia's renewable energy efforts. Extensive literature review was conducted and a comparative analysis were performed to further the understanding of vital modifications and inclinations historically involving the evaluation and assessment of Malaysia's renewable energy policies, its framework as well as its implementation guidelines. These reviews would contribute in developing a policy-writing management framework based upon the SWOT analysis of Malaysia's renewable energy policies. This was then developed to further improve the structural stance of current policies to ensure effective implementation of large-scale renewable energy projects in Malaysia.
\end{abstract}

Index Terms-Project management, renewable energy, policy, Malaysia.

\section{INTRODUCTION}

Policymakers often face the challenge of providing a consistent, inexpensive, maintainable, secure and low carbon energy supply. This is particularly true for Malaysia; with a population of 28 million whilst electricity remains unavailable to a significant proportion of the population [1], [2].

With the gradual depletion of fossil fuels, renewable energy (RE) is seen as one of the viable solution to Malaysia's energy needs. Despite the numerous RE policies implemented there appears to be a gap prohibiting effective implementation due to factors such as insufficient knowledge and public awareness [3], [4]. Hence, this paper aims to investigate the lack of, and to identify and recommend, a suitable management framework to facilitate the implementation of RE policies in Malaysia.

\section{BACKGROUND AND MOTIVATION}

Energy related policies have been drawn by Malaysia's

Manuscript received March 17, 2015; revised September 26, 2015

P. Y. Ong was with the Department of Mechanical, Materials and Manufacturing Engineering, University of Nottingham, Malaysia Campus, 43500 Semenyih, Selangor, Malaysia (e-mail: jacy.ongpy@gmail.com).

C. M. M. Chin is with the Department of Mechanical, Materials and Manufacturing Engineering, University of Nottingham, Malaysia Campus, 43500 Semenyih, Selangor, Malaysia (e-mail Christina.Chin@nottingham.edu.my).

E. H. Yap is with UCL School of Energy and Resources (UCL Australia), University College London, Adelaide, SA 5000, Australia (e-mail: e.yap@ucl.ac.uk). policymakers since 1949 to drive the country's sustainability development. However, barriers such as unrealistic expectations, communication barriers, and a lack of public awareness and support have hindered successful implementation of these policies [5]. The objective for this project is not only to provide RE policy formulation guidance for policymakers, since the deployment of RE contributes considerably to the economy [6], but to also recommend project management $(\mathrm{PM})$ methodologies in the RE industry especially during the implementation of RE policies [7].

The research methodology adopted in this paper consists of a literature review of RE policies worldwide thus comparing data between developed and developing countries, as well as developing a SWOT analysis of Malaysia's current RE policies and their implementation so that these can be integrated into a suitable project management framework.

A thorough literature review conducted revealed the following: World Summit for Sustainable Development reported that climate change, pollution and potential loss of biodiversity and other social issues are consequences of climate change which have triggered the need for RE [8]. With energy consumption exponentially increasing whereas conventional fuel supply e.g. oil and gas decreasing, the need for extraction of energy which can be derived from natural, inexhaustible resources such as sunlight, wind, rain, tides, and geothermal heat has been identified [9]. With the availability of these RE resources, this drives the potential of gearing the world's concurrent emerging economic state to a more sustainable future [6].

A review of RE policies for a number of nations was conducted with a view to distinguish efforts, barriers, and subsequently the path that each country is taking to achieve a sustainable development to further enhance the understanding of the implementation process before developing a feasible framework.

\section{A. Developed Countries}

A developed country is one which possesses a high development level according to predetermined economic criteria e.g. revenue per capita, industrialisation, and recently introduced Human Development Index (HDI) [10]. For a comparative analysis, five countries active in the development of RE were put into consideration e.g. Australia, Germany, Japan, United Kingdom, and United States.

An analysis conducted by World Bank [11], [12] indicates that these countries are making significant efforts to assimilate RE into their country's sustainable development plan. For instance, Australia's Renewable Energy Target (RET) in 2009, and Germany's Renewable Energy Sources Act in 2000 have comparable goals: to reduce dependency on 
fossil fuels and consequently increase RE's fraction in the country's energy mix [13]. Similarly, the US has also incorporated strategies which were found to be diverging in terms of implementation; these have slowed down the country's RE growth compared to Germany [14].

In spite of positive economic and technological circumstances in these countries, the lack of a governing framework, financial sustenance, technical capability [15] and social approval (licensing) were found to be impeding. A governing framework is highly prioritised by these developed countries as efficient and effective management is often needed for the implementation of these policies.

\section{B. Developing Countries}

Developing countries namely the BRIC constituents: Brazil, Russia, India, and China were considered in this paper in a comparative analysis. Similarly, they have also realised the need for RE. Brazil is known to be rich in resources such as solar, wind, hydro, ethanol, and biodiesel [16]. Efforts to promote biomass as a viable form of energy were carried out to boost growth in ethanol and biodiesels e.g. Brazil Ethanol Program and Production and Use of Biodiesel [17]. Alternative Sources Incentive Program (PROINF) in 2002, and Ten Year Energy Expansion Plan (PDE), which were developed around the Brazilian Clean Energy Scenario, has also been employed to diversify its energy supplies and to reduce its energy imports [16], [18].

Since the accident which have caused the destruction of Russia's Sayano-Shushenkaya hydropower plant in 2009, there was an urgent need for significant energy development in the country. Common support policies and capacity-based support schemes share a similar objective, which is to increase the number of electricity production investors [19]. Since the establishment of the federal law on energy efficiency, there have been a number of policies built around it e.g. Energy Strategy to 2030 and Federal Energy Efficiency Program [19].

Energy policies such as Energy Conservation Law in 2001, Electricity Act 2003, Integrated Energy Policy in 2006, and recently the National Action Policy on Climate Change have been implemented by India to highlight the importance of diversifying energy supply. It is aimed that India's energy mix should comprise of $15 \%$ from RE sources by 2020 [20].

China has taken a significant step since mid-1980s to mitigate climate change and to diversify its depleting fossil energy resources with the enactment of Renewable Energy Law. That was the beginning of an energy revolution in the country [21]. There have been several policies outlining the continual need for RE, which targeted a usage of $10 \%$ of RE by 2010 , and then $16 \%$ by 2020 . However, these initiatives were found to be lacking long-term goals, social acceptance, sufficient financing schemes, and investment for extensive $\mathrm{R} \& \mathrm{D}[21]$.

\section{Renewable Energy Policies in Malaysia}

According to Rakob, Malaysia is heavily dependent upon oil, natural gas, hydropower, and coal for its electricity generation sector [22]. However, the National Energy Policy in 1979 has triggered a progress for Malaysia where other major energy policies complying to Malaysia Plans e.g. the National Depletion Policy (1980), Four-fuel Diversification Policy (1981), Renewable Energy as the Fifth Fuel Policy (2000) and Small Renewable Energy Programme (SREP) (2001) (shown in Table I). These policies were primarily developed based upon the National Energy Policy [23], [24]. In 2001, Malaysia started the implementation of small scale Feed-in Tariff (FiT) mechanism in SREP, confirming definite access to the utility distribution grid, 21-year contracts from the time of commissioning and cost-based acquisition fees [25].

\section{Project Management Body of Knowledge (PMBOK)}

The Project Management Institute (PMI) explains that in order to accomplish a set of goals and visions, there is a range of actions that can be utilised to plan, organise, direct, control, motivate, and evaluate roles by highlighting ten bodies of project management (PM) knowledge specifically integration, scope, time, cost, quality, human resource, communications, risk, procurement, and stakeholders [26].

TABLE I: MAJOR ENERGY POLICIES IN MALAYSIA FROM 1949-2013 [5]

\begin{tabular}{|c|c|c|}
\hline \multicolumn{3}{|c|}{ Major Energy Policies/Events in Malaysia from 1949-2013 } \\
\hline Year & Policy/Event & Main Agenda \\
\hline 1949 & Central Electricity Board & Authoritative board in integrating electricity production, transmission, and supply \\
\hline 1974 & Petroleum Development Act & $\begin{array}{l}\text { The conferring of all petroleum-related resources to Petroleum National Berhad } \\
\text { (PETRONAS), a wholly owned governmental body }\end{array}$ \\
\hline 1975 & National Petroleum Policy & $\begin{array}{c}\text { To deliver appropriate regulatory guidelines for Malaysia's oil and gas industry in } \\
\text { attaining pre-set economic goals and objectives }\end{array}$ \\
\hline 1979 & National Energy Policy & $\begin{array}{c}\text { To assist as a pivot policy which focuses on three ideas: supply, utilisation, and } \\
\text { environmental }\end{array}$ \\
\hline 1980 & National Depletion Policy & To assure an effective and safe utilisation of natural reserves, especially oil \\
\hline 1981 & $\begin{array}{l}\text { Four-Fuel Diversification } \\
\text { Policy }\end{array}$ & $\begin{array}{l}\text { To avoid over-reliance on oil whilst confirming dependability of oil, gas, hydro and } \\
\text { coal in Malaysia energy mix }\end{array}$ \\
\hline 1990 & Electricity Supply Act & $\begin{array}{l}\text { To function as a governing organisation in the electricity supply industry, ensuring } \\
\text { sensible energy prices, permitting and monitoring of electrical installations, and } \\
\text { encouraging competent electricity usage }\end{array}$ \\
\hline 2001 & $\begin{array}{l}\text { Five-Fuel Diversification } \\
\text { Policy }\end{array}$ & To introduce RE as the fifth source in the energy mix \\
\hline 2001 & $\begin{array}{l}\text { Small Renewable Energy } \\
\text { Power (SREP) Programme }\end{array}$ & $\begin{array}{l}\text { To endorse rigorous practice of RE in small scale projects, sustained by the } \\
\text { enactment of Special Committee on Renewable Energy (SCORE) }\end{array}$ \\
\hline 2001 & Energy Commission Act & $\begin{array}{l}\text { To control commercial and monetary performance and supervision of the energy } \\
\text { industry in Malaysia (based on Electricity Supply Act and its subsidiary policies) }\end{array}$ \\
\hline 2006 & National Biofuels Policy & $\begin{array}{l}\text { To lessen needs for fossil fuels, promoting use of palm oil and stabilising its price } \\
\text { in the energy market countrywide and worldwide }\end{array}$ \\
\hline 2009 & $\begin{array}{l}\text { National Green Technology } \\
\text { Policy }\end{array}$ & $\begin{array}{l}\text { To increase the development of green technology in Malaysia whilst keeping } \\
\text { adequate competitiveness internationally, and building cognisance for prospective } \\
\text { generations }\end{array}$ \\
\hline 2011 & New Energy Policy & $\begin{array}{l}\text { To begin initiating a secure and managed energy supply by stimulating RE usage, } \\
\text { consolidating governance, and embracing market-based energy pricing }\end{array}$ \\
\hline
\end{tabular}




\section{SWOT ANALYSIS OF MALAYSIA'S RENEWABLE ENERGY POLICIES}

\begin{tabular}{|c|c|}
\hline $\begin{array}{l}\text { Strengths } \\
\text { - Acknowledges } \\
\text { Malaysia's necessity for } \\
\text { sustainability [6] } \\
\text { - Offers a method of } \\
\text { governance [12] } \\
\text { - Determines objectives to } \\
\text { be attained [36] } \\
\text { - Encourages worldwide } \\
\text { collaboration [39] }\end{array}$ & $\begin{array}{l}\text { Weaknesses } \\
\text { - Lack of regulatory } \\
\text { framework [7] } \\
\text { - Inadequate cost and } \\
\text { knowledge [7] } \\
\text { - Inadequate research [7] } \\
\text { - Lack of public support } \\
\text { [9] } \\
\text { - Lack of RE statistics } \\
\text { - I5] } \\
\text { policy aims [5] }\end{array}$ \\
\hline $\begin{array}{l}\text { Opportunities } \\
\text { - Increases RE } \\
\text { contribution globally } \\
\text { [39] } \\
\text { - Increases employment } \\
\text { rate [9] } \\
\text { - Decreases dependency } \\
\text { on conventional fuels } \\
\text { [3] } \\
\text { - Energy efficiency [39] } \\
\text { - Avenue for improved } \\
\text { governance [34] }\end{array}$ & $\begin{array}{l}\text { Threats } \\
\text { - Continual shifting of } \\
\text { international RE } \\
\text { policies and standards } \\
{[6]} \\
\text { - New RE technology } \\
\text { [37] } \\
\text { - Stakeholders losing } \\
\text { motivation [38] } \\
\text { - Public disapproval [5] } \\
\text { - Political conflicts [37] } \\
\text { - Economic inflation } \\
{[26] \text { }}\end{array}$ \\
\hline
\end{tabular}

After reviewing Malaysia's RE policies, a SWOT analysis (shown in Table II) was created to facilitate the development of the framework which will be addressed in the next section. The need to identify alternative energy sources was determined since Malaysia's Sixth Malaysia Plan in 1991, thus distinguishing it as one of the strengths attributed in the analysis. These strengths and opportunities include increased RE participation worldwide whilst boosting employment rate in the country [9] further encourage the deployment of RE in Malaysia. A lack of regulatory framework and public support [24] are examples of significant weaknesses and threats identified during the reviewing process which will serve as a form of leverage in designing the framework.

\section{COMPARATIVE ANALYSIS OF RE POLICIES WORLDWIDE AND MALAYSIA}

The literature review conducted shows a trend in both developed and developing countries where there were continuous effort to increase the share of RE in their countries. For example, Germany and US have less difficulties in implementing RE compared to Malaysia because their governments provide strong enforcements and support [27], [28]. Despite the differences in HDI, these countries including Malaysia face similar challenges as seen in aforementioned SWOT analysis, and these will be used as the basis to design the management framework for Malaysia.

\section{DeVelopment of a Project Management FRAMEWORK}

According to Bloom's taxonomy, knowledge, comprehension, application, analysis, synthesis, evaluation, and creation are important to effectively carry out a project thus making it relevant to understand the association between policy-making and project management [29]. In order to meet the aim of this research, the development of a PM framework for RE policies implementation in Malaysia is imperative.
The developed framework aims to achieve the following criteria: clear, transparent, effective, consistent, and compliant [30] as the purpose of a framework in this case, is to be a conceptual structure which serves as a support or guide.

\section{A. Integration of Project Management and Renewable Energy Policy Implementation}

There are disadvantages to relating RE with PM such as incompetency in terms of technological understanding, e.g. in the palm oil industry; a majority of people would be expected to only have partial understanding in advanced boiler technology [5]. Past involvements in countries such as Germany and China highlighted that in spite of the application of standard PM methodology in Germany, subsequent result was found to be non-satisfactory [28]. The difficulty to penetrate each relevant $\mathrm{RE}$ element as well as a generic methodology were found to be obstructing. Moreover, feasibility studies are often expensive, causing lost in motivation for most developers and investors to continue pursuing RE projects [30]. Overall non-compliance of RE conception and projects in Malaysia were majorly caused by institutional flaws such as capacity capping and ineffectively formulated national policy frameworks [6]. Thus this project realises the essentiality to develop a suitable PM framework that aims to overcome these difficulties by assisting the policy-writing and implementation process of RE policies in the country.

\section{B. Developed Framework and Justifications}

According to PMBOK, PM is an integrative endeavor where an action, or failure to take action, would normally affect other areas [26]. There are necessary stages to be taken before implementation. For example, the finalised policy has to be submitted to the authoritative board and stakeholders for approval before it could be implemented fully, otherwise corrective action has to be taken again to further improve the policy [31]. In each of the lower level processes, there are tools and techniques recommended by PMI to transform inputs into outputs [26]. The framework, as shown in Fig. 1, comprises of five stages: identifying the goals, planning the policy-writing, writing the policy, monitoring and controlling the policy, and submitting the policy.

\section{CONCLUSION AND FURTHER WORKS}

This paper proposed a framework integrating the policy-writing process and its implementation using project management methodology, taking through the literature review on some selected nations', and Malaysia's, RE policies. A comparative analysis yielded a SWOT analysis of Malaysia's own RE policies. This study highlighted the importance of understanding the policy development process before a management framework could be designed as a tool to provide information and to serve as a guide to RE policy-makers. The proposed framework could be used as a guide to RE policy implementation as it can ensure management consistency. However, it is imperative to take into view that such a framework could be problematic when only a superficial top level perspective, e.g. ministerial level, 
is considered. Therefore, expansion, or more importantly, substantiation, of the framework into its downstream constituents has to be considered. These should comprise of work inputs/outputs, tools and techniques which could be utilised; a continuous improvement mind-set to adapt to various scope, managerial, and legislative factors alongside with vigorous and practical testing of the framework by relevant parties.

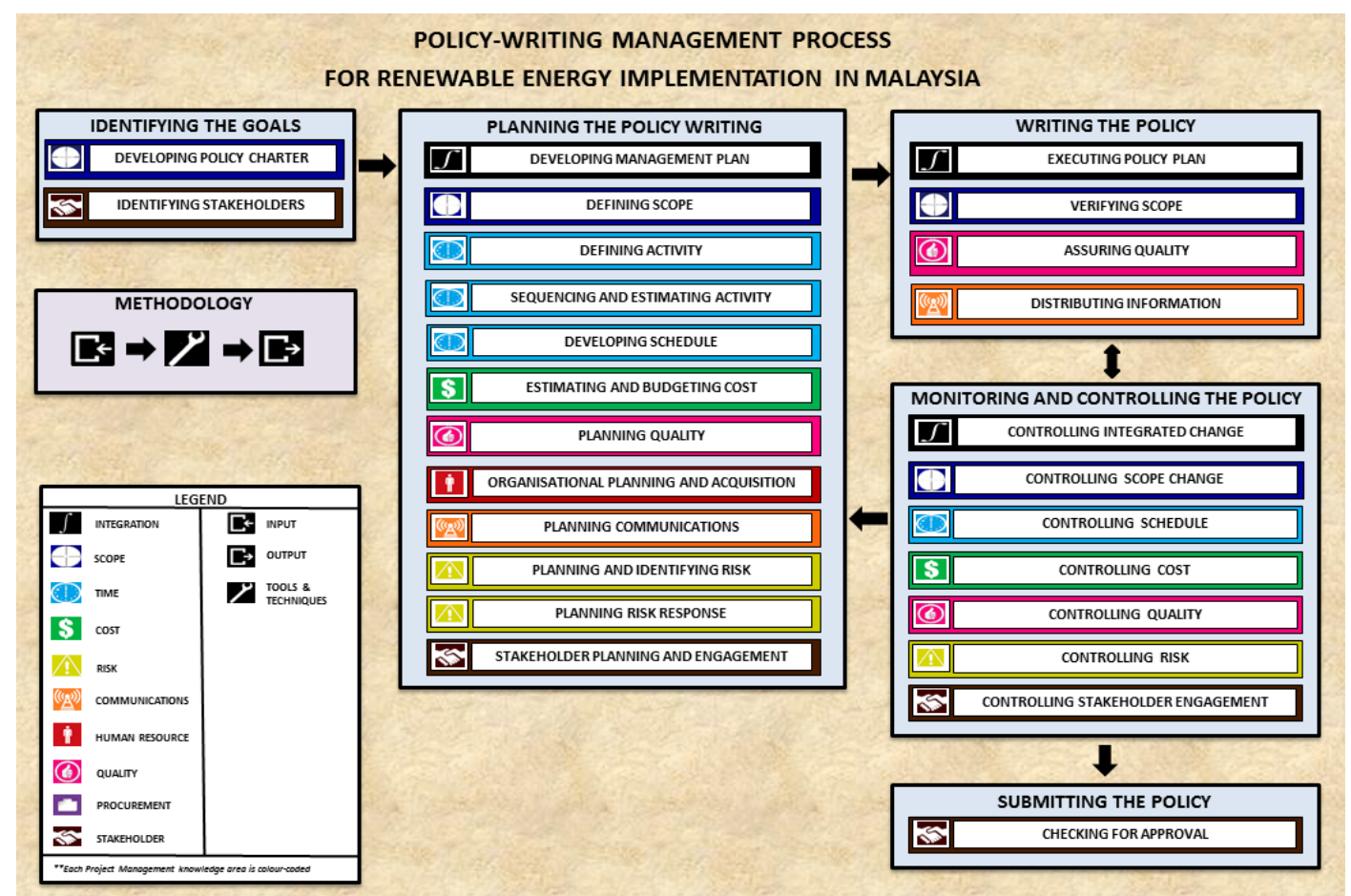

Fig. 1. Developed framework for RE policy-writing processes in Malaysia.

\section{REFERENCES}

[1] Population Distribution and Basic Demographic Characteristics, Department of Statistics Malaysia, 2010.

[2] The Malaysian Economy in Figures in 2012, Economic Planning Unit, Prime Minister's Department, Malaysia, 2012.

[3] M. N. Dalimin, "Renewable energy update: Malaysia," Renewable Energy, vol. 6, no. 4, pp. 435-439, June 1995.

[4] Central Intelligence Agency (CIA). CIA - The World Factbook. [Online]. Available: http://goo.gl/ve8Vaw

[5] B. Sovacool and I. M. Drupady, "Examining the small renewable energy power (SREP) program in Malaysia," Energy Policy, vol. 39, no. 11 , pp. 7244-7256, November 2011.

[6] M. R. F. Zonooz, B. Ali, K, Sopian, and O. Saadatian, "Review of current national energy policies in Malaysia,' in Proc. $3^{\text {rd }}$ International Conference on Business and Economic Research, 2012, pp. 898-909.

[7] Enabling Efficient Policy Implementation, Economist Intelligence Unit, London: The Economist Group, 2010.

[8] World Summit on Sustainable Development. [Online]. Available: http://goo.gl/z21Jui

[9] T. S. Jalal and P. Bodger, "National energy policies and the electricity sector in Malaysia," in Proc. $3^{\text {rd }}$ International Conference on Energy and Environment, 2009, pp. 385-392.

[10] Developed country. [Online]. Available: http://goo.gl/0spoiy

[11] $\mathrm{CO}_{2}$ Emissions (metric tonne per capita). [Online]. Available: http://goo.gl/nyQ84I

[12] Electricity production from renewable sources $(\mathrm{kWh})$. [Online]. Available: http://goo.gl/yyZ44I

[13] Energy Policies of IEA Countries - Australia and Germany, International Energy Agency (IEA), 2012.

[14] F. N. Laird and C. Stefes, "The diverging paths of Germany and United States policies for renewable energy: Sources of difference," Energy Policy, vol. 37, no. 7, pp. 2619-2629, 2009.

[15] L. Byrnes, C. Brown, J. Foster, and L. D. Wagner, "Australian renewable energy policy: Barriers and challenges," Energy Policy, vol. 60, pp. 711-721, December 2013

[16] A. O. Pereira, R. Cunha da Costa, C. do Vale Costa, J. de Moraes Marreco, and E. Lèbre La Rovere, "Perspectives for the expansion of new renewable energy sources in Brazil," Renewable and Sustainable Energy Reviews, vol. 23, pp. 49-59, July 2013.

[17] H. Zhang, L. Lo, J. Cao, M. Zhao, and Q. Wu, "Comparison of renewable energy policy evolution among the BRICs," Renewable and Sustainable Energy Reviews, vol. 15, pp. 4904-4909, December 2011.

[18] H. Geller, R. Schaeffer, A. Szklo, and M. Tolmasquim, "Policies for advancing energy efficiency and renewable energy use in Brazil," Energy Policy, vol. 32, no. 12, pp. 1437-1450, August 2004.

[19] A. Boute, "Promoting renewable energy through capacity markets: An analysis of the Russian support scheme," Energy Policy, vol. 46, pp 68-77, July 2012.

[20] A. Mahesh and K. S. Jasmin, "Role of renewable energy investment in India: An alternative to $\mathrm{CO}_{2}$ mitigation," Renewable and Sustainable Energy Reviews, vol. 26, pp. 414-424, October 2013.

[21] P. Zhang, Y. Yang, S. Jin, Y. Zheng, L. Wang, and X. Li, "Opportunities and challenges for renewable energy policy in China," Renewable and Sustainable Energy Reviews, vol. 13, no. 2, pp 439-449, February 2009.

[22] M. Y. Rakob, "Planning for smart grid in TNB system," in Proc. IEEE Conference on Power and Energy Proceedings, Kuala Lumpur, 2010.

[23] A. Maulud and H. Saidi, "The Malaysian fifth fuel policy: Re-strategising the Malaysian renewable energy initiatives," Energy Policy, vol. 48, pp. 88-92, September 2012.

[24] S. I. Mustapa, Y. P. Leong, and A. H. Hashim, "Issues and challenges of renewable energy development: A Malaysian experience," in Proc. International Conference on Energy and Sustainable Development Proceeding, pp. 1-6, 2010.

[25] S. C. Chuah and T. H. Oh, "Review on Malaysia's national energy developments: Key policies, agencies, programs and international involvements," Renewable and Sustainable Energy Reviews, vol. 14 no. 9 , pp. 2916-2925, 2010.

[26] A Guide to the Project Management Body of Knowledge, Pennsylvania: Project Management Institute, 2000

[27] J. Huenteler, T. S. Schmidt, and N. Kanie, "Japan's post-Fukushima challenge - implications from the German experience on renewable energy policy," Energy Policy, vol. 45, pp. 6-11, June 2012.

[28] T. Pregger, J. Nitsch, and T. Naegler, "Long-term scenarios and strategies for the deployment of renewable energies in Germany,' Energy Policy, vol. 59, pp. 350-360, August 2013. 
[29] B. S. Bloom, Taxonomy of Educational Objectives: The Classification of Educational Goals; Handbook I: Cognitive Domain, New York: Longmans, 1956.

[30] E. G. Too and P. Weaver, "The management of project management: A conceptual framework for project governance," International Journal of Project Management, vol. 32, no. 8, pp. 1382-1394, November 2014.

[31] J. P. Painuly, "Barriers to renewable energy penetration; a framework for analysis," Renewable Energy, vol. 24, no. 1, pp. 73-89, September 2001.

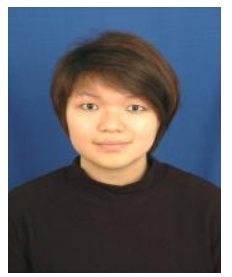

Pei Yee Ong graduated with a MEng (Hon) degree in mechanical engineering from University of Nottingham, Malaysia Campus. She joined the university in 2010.

She is currently a functional analyst in Materialize in Petaling Jaya, Malaysia. Whilst at the University of Nottingham Malaysia Campus, she worked under the supervision of Dr. Christina Chin in the area of project as her final year research. management and renewable energy policy in Malaysia

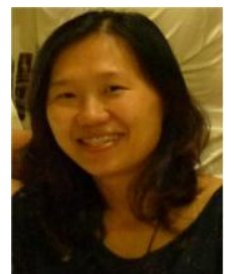

Christina May May Chin is an assistant professor with the Department of Mechanical, Materials \& Manufacturing Engineering, University of Nottingham, Malaysia Campus. She obtained her PhD degree from the university in 2011. Her main interest remains with project management with more emphasis on designing a methodology for use to managing complex, yet dynamic collaborative research between university academicians and industry partners, which she is working on publishing it to aid institutional in research environment.

Christina also looks into technological innovation in knowledge intensive industries. Apart from this area of interest, she is also conducting research in the area of renewable energy policies management and implementation with the adoption of project management concepts and techniques, pollution management for river basin conservation programme for Malaysia and lean concepts and management in the manufacturing industries.

Being in the academia and the industry for more than ten year, Christina has published and presented in major conferences and contributed to the body of knowledge; supervised a number of undergraduates and postgraduates (MSc and PhDs). She is also very active as a reviewer for the Engineering Management Research Journal.

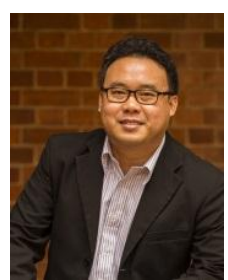

Eng Hwa Yap is a senior member of IACSIT. He obtained his $\mathrm{PhD}$ degree from University College London, United Kingdom in 2009 and BSc (Hon) degree in marine technology from University of Plymouth, United Kingdom in 2002. He has also completed a postgraduate certificate in higher education at University of Nottingham, Malaysia Campus in 2014.

$\mathrm{He}$ is currently a senior lecturer at UCL School of Energy and Resources, University College London in Adelaide, Australia. He was formerly an associate professor at the Department of Mechanical, Materials and Manufacturing Engineering at the University of Nottingham, Malaysia Campus where he served as the course director for MSc in mechanical engineering and later the course director for UG programs. His research work is focused on sustainable system dynamics modeling using energy technologies. He looks into the dynamics of such technologies' integration within the community with a focus on emerging economies.

Dr. Yap is a fellow of the Higher Education Academy, United Kingdom. He was awarded the CESA smart award for European Maritime Visions in 2007, jointly with Prof (then Dr.) Richard Bucknall, being the first awardee from a British university. Dr. Yap served in the technical committee for a number of international conferences and reviewed for a number of peer-reviewed journals including Journal of Clean Energy Technologies and Journal of Engineering, Science and Technology. 